\author{
Yurii Vinogradov \\ https://doi.org/10.26485/AAL/2019/65/10
}

\title{
BOSPORAN TUMULUS WITH IMPRINT OF RHODIAN COIN
}

\begin{abstract}
In the Hellenistic period Rhodes was an important centre of trade and wine production. Finds of Rhodian amphorae stamps are very common in the Northern Black sea region, but Rhodian coins are quite rare. Some finds from the tumuli of the Cimmerian Bosporus demonstrate Rhodian influence also. One tumulus excavated on the Tuzla cape (the Taman peninsula) in 1885 is especially interesting. A rich grave dating to the end of the 3rd or beginning of the 2nd century BC was excavated. The grave inventory consists of two Greek vases, one gold wreath, a silver ladle (kyathos), a silver strainer of unusual form, and a silver footless bowl of mastos type, bearing a gold indication of a Rhodian coin. It is the only find of such type in the aristocratic burials of the Bosporan Kingdom.
\end{abstract}

Keywords: Cimmerian Bosporus, tumuli, Rhodian trade, Greek coins, indications

ABSTRAKT W okresie hellenistycznym Rodos było ważnym centrum handlu i produkcji wina. Rodyjskie amfory opatrzone stemplami są bardzo liczne na terenie północnego wybrzeża Morza Czarnego. Znaleziska rodyjskich monet są na tym terenie niezmiernie rzadkie. Powiązania Bosforu Kimmeryjskiego z Rodos potwierdzają jednak również zabytki, będące wyposażeniem grobów. Przebadany archeologicznie w 1885 r. kurhan na przylądku Tuzla (Półwysep Tamański) dostarczył interesujące materiały. W bogatym grobie, datowanym na koniec III - początek II w. p.n.e., znaleziono wiele wyrobów greckich. Pomiędzy wydobytymi zabytkami była złota blaszka, której wygląd sugeruje odciśnięcie jej na rodyjskiej monecie.

Słowa kluczowe: Bosfor Kimmeryjski, kurhany, handel rodyjski, monety greckie

When we discuss contacts between the Greek states of the Northern Black Sea area with Rhodes, everyone thinks of the huge number of Rhodian amphorae stamps from the Hellenistic sites all over this region. ${ }^{1}$ But, the question of how much influence Rhodes had on the culture of the Bosporan aristocracy has not been considered in the archaeological literature. This question has never been raised, although its importance is quite obvious. Such influence, as is hardly difficult to guess, we can trace exclusively on the basis of finds from the elite burials of the Cimmerian Bosporus: finds which can be somehow be connected with the famous island.

One find of this category is the well-known silver cup, which comes from one of the tombs belonging to the necropolis on the Karantien road near Kerch. ${ }^{2}$ This necropolis dates to the 3 rd century BC.

1 See for instance Шелов 1975: 10-127; Кац 2007: 202-220.

2 Gorbunova, Saverkina 1975: cat. 99; Trofimova 2007: 170-171, cat. 74 .
The relief image of Helios driving his chariot, which appears on its base, clearly alludes to the main deity of Rhodes.

A similar image is, however, also displayed on an object coming from an earlier burial complex, but we only know of it from archival materials stored in the Institute for the History of Material Culture in St. Petersburg. This object was found during the excavations of the Yuz-Oba ('Hundred Hills') necropolis: the famous kurgan necropolis near Kerch in which were buried members of the Bosporan nobility of the 4th century BC. Along with a huge single tumulus reaching $17 \mathrm{~m}$ in height, it also contains a number of relatively modest small barrows (measuring $7 \mathrm{~m}$ or less). One of them, the 'Second Small' barrow, was excavated in $1863 .^{3}$ The stone tomb which was found contained unusually rich furnishings (Fig. 1): a red-figure vase, a gold finger-ring, an iron sword, bronze arrowheads, and some other

3 Виноградов, Зинко, Смекалова 2012: 109-111, 278 , рис. 78 . 


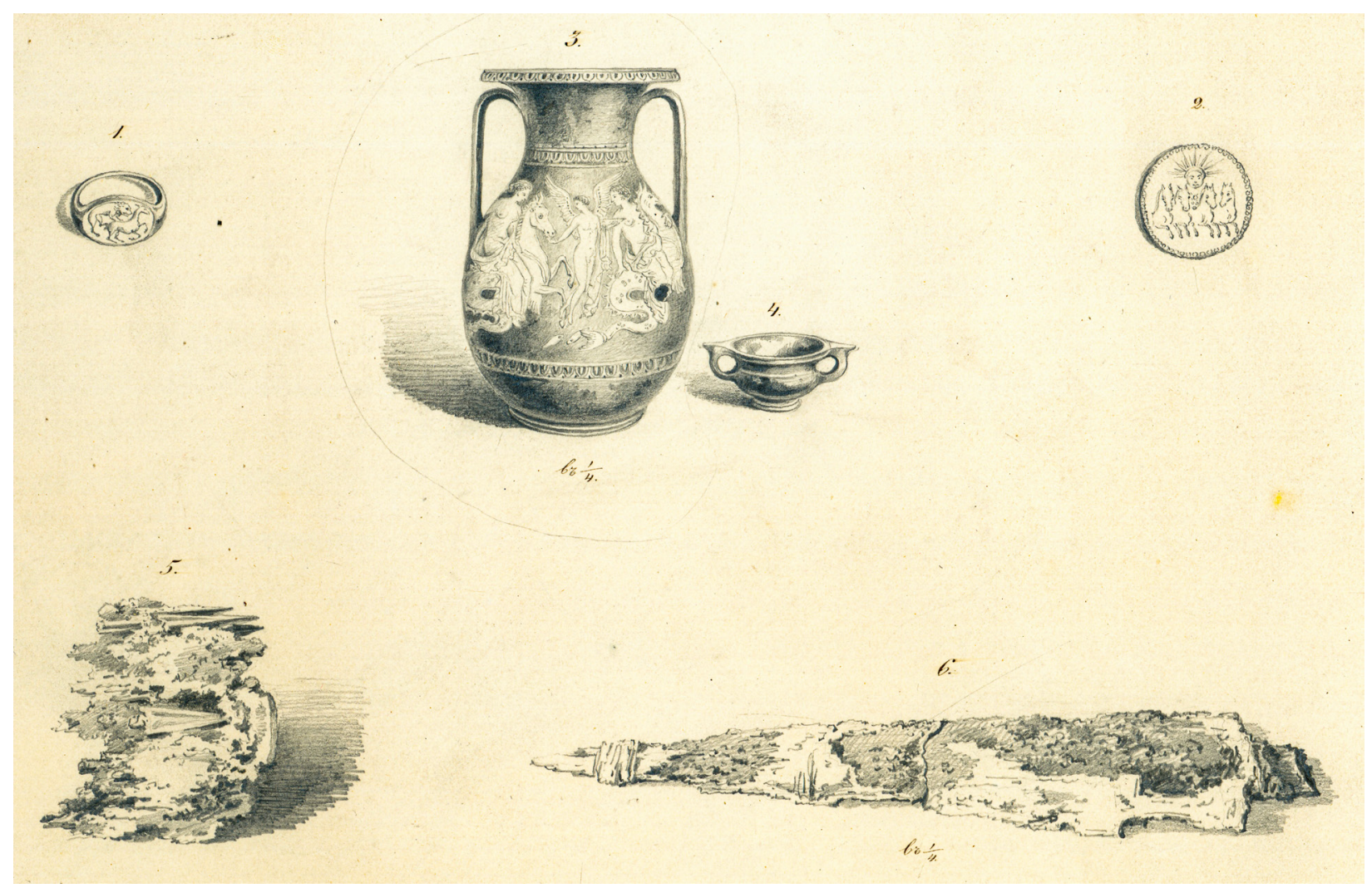

Fig. 1. Finds from the Second Small tumulus of the Yuz-Oba necropolis (drawing by F.I. Gross)

objects. ${ }^{4}$ A gold disk, on which the image of Helios in a radiant crown on the chariot was imprinted, is especially interesting in this context (Fig. 1, 2). This tomb certainly belongs to the second half of the 4th century BC, and most likely to the end of the century. In other words, interest in Rhodes among members of the Bosporan aristocracy was already apparent before the 3rd century BC.

In this context it is, of course, impossible to fail to mention the finds from the Fedulovsky hoard, which was found on the left bank of the River Don in 1904. This hoard included a number of ornamental horse harness elements. The most spectacular of these are the plaques (or phalera). Of course, the big phalera, decorated with lions' heads, are very famous, but a small silver plaque decorated with the image of Helios and horses' heads is no less interesting. ${ }^{5}$ In my opinion, the Fedulovsky treasure should not be dated to the end of the 3rd century BC, as it usually is, but rather to the middle of the century. ${ }^{6}$ In other words, it can be stated that the image of Helios first became popular in the Northern Black

4 Виноградов, Зинко, Смекалова 2012: 110, рис. 79.

5 Mordvinceva 2001: 71, Taf. 2, 4; Спицын 1909:

39 , рис. 45 ; Засецкая 1965: 31, рис. 3 .

6 Виноградов 2006: 218-219.
Sea region at the turn of the 4th / 3rd centuries BC. Previously it was absolutely unknown there. Such a metamorphosis, in my opinion, could be associated with the rapidly growing influence of Rhodes.

The repertoire of objects in the richer tombs of the Bosporus associated with this island is not limited to these two works of art, but information about an additional one has only come to light quite recently. The old excavations of the kurgan necropolis located on the cape of Tuzla (the Taman Peninsula) are very important for the study of culture of the elite living in the Asian part of the Bosporus, and, of course, for the study of the culture of the Bosporus as a whole. Researchers have traditionally paid more attention to the early burials discovered here, dating back to the 6 th -5 th centuries $\mathrm{BC},{ }^{7}$ and such attention, of course, has its own justification. However, very interesting objects of the 4th century $\mathrm{BC}$ and even later are represented in the materials coming from the necropolis. One of these 'late' complexes is the main subject of this paper.

In 1885-86 the director of the Kerch Museum of Antiquities F.I. Gross conducted excavations at Cape Tuzla. He was a capable draughtsman, and he has left us numerous drawings of Bosporus kurgans, 


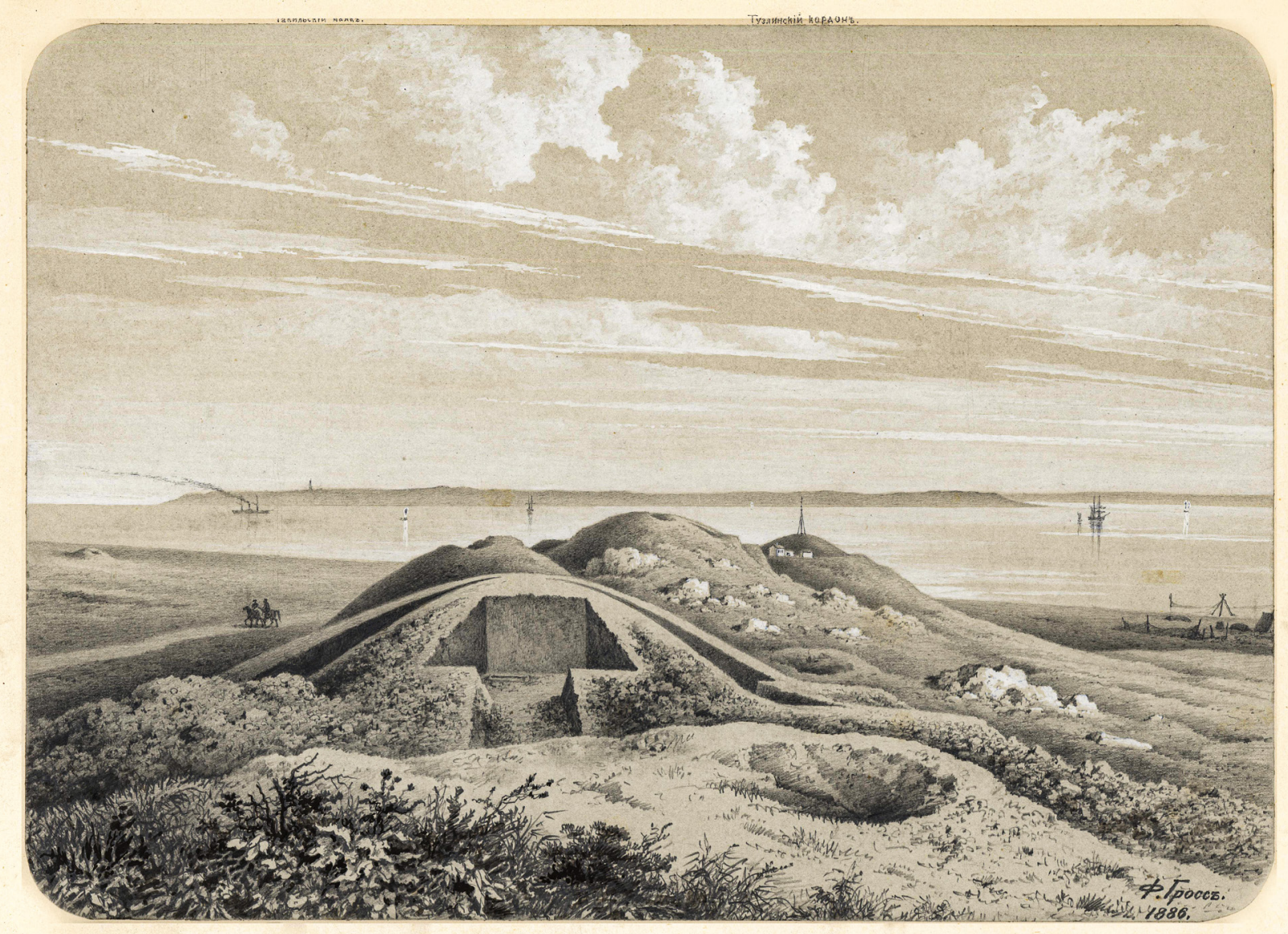

Fig. 2. Excavations on Tuzla cape (drawing by F.I. Gross)

ancient settlements, ancient tombs, together with the remarkable finds which came from them, etc. ${ }^{8}$ Without these pictures, our knowledge of Bosporan antiquities would be very much more limited, deprived of a significant part of the pictorial record, and therefore of the imagery, brightness and charm which abound in the drawings of the mounds of the Tuzla cape (Fig. 2) which F.I. Gross made. There is nothing to be seen resembling the drawings of F.I. Gross nowadays, only steppe the Tuzla cape, only steppe landscape. He wrote in his report on the excavations wrote that these mounds for the most part were piled on natural rocky hills 'and therefore not as large as they appear at first glance'. Practically all of them were robbed, 'only some of tombs in the periphery sides of the mounds survived, probably, because of ignorance of the robbers of their locations'?

F.I. Gross excavated a total of 11 mounds in the Tuzla necropolis. For a long time, the results of these studies did not attract the attention of scientists, and only recently the St. Petersburg archeologist

8 Виноградов 2017а: 22-35, 76-213, табл. 30-163.

9 Виноградов 2016: 19 .
S.V. Kashaev collected all the archival materials related to the excatations of F.I. Gross and published a lengthy article about these tumuli. ${ }^{10}$ My paper is dedicated to only one of them.

From archival materials, it appears that F.I. Gross excavated the Fifth Barrow, which lay on the left side of the road from Taman to the Tuzla cordon. Tomb, at the beginning of June in 1886 . Tomb No. 57 was discovered in the eastern side of this tumulus. The materials coming from this tomb allow us to form a general idea about its function, and confidently to date it to the Hellenistic period. The complex as a whole, however, deserves more attention. ${ }^{11}$

Tomb no. 57 was built of stone slabs, also covered with slabs of stone. Its internal dimensions were, length: almost $2 \mathrm{~m}$, width: $90 \mathrm{~cm}$, depth: $70 \mathrm{~cm}$. Speaking in general terms, it was a Bosporan grave of the normal type found. In the tomb was found a skeleton with a fairly rich set of equipment. Lying beside the skull were two vases (Fig. 3).

10 Кашаев 2009.

11 Виноградов 2016; 2017a: 249-250; 2017б: 206-208. 


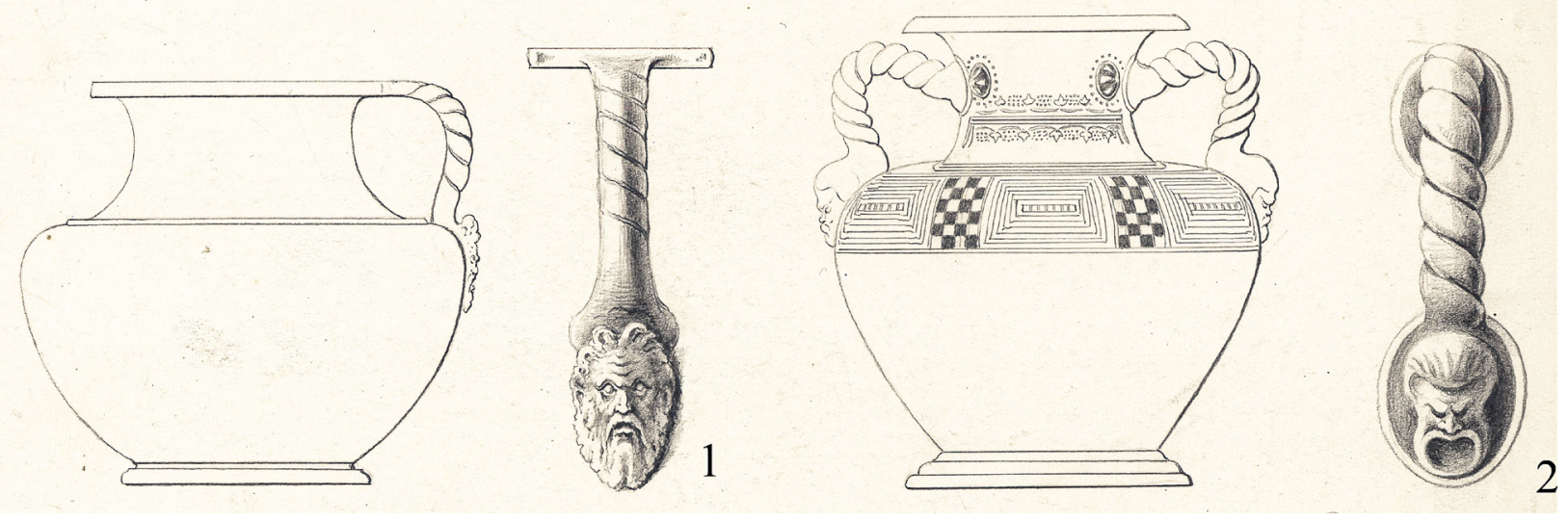

Fig. 3. Vases from Tomb 57 (drawing by F.I. Gross)

There were also gold and silver objects (Fig. 4). A golden wreath and a golden impression (or coin shape appliqué) were found on the skull; a silver bowl, decorated with a 'border of balls', as described by the excavator was near the right hand. A silver ladle was found near the left hand of the skeleton, and a silver strainer, a piece of sponge, and a piece of skin 'with red powder' were found also there.

Let us examine these finds in detail. One of the vases is a black-glazed jug with a single twisted handle, which is decorated with a relief where it joins with the body (Fig. 3, 1). According to F.I. Gross, the head belonged to Zeus, but it is more likely to be the head of Dionysus or a Satyr. By way of analogy, there is a similar hydria from the Artyukhovsky kurgan, ${ }^{12}$ the most important monument demonstrating the aristocratic culture of the Bosporus during the 2nd century BC.

The second vase is a black-glazed amphora with two twisted handles, each decorated with a theatrical mask where it joins the body (Fig. 3, 2). It is decorated with an ivy garland around the throat. A geometric pattern characteristic for 'western slope' pottery appears on the shoulders. This vessel also has analogies with material from the Artyukhovsky kurgan. ${ }^{13}$

It is also known that there was a large blackglaze dish near the right hand of the skeleton, but it was not recorded in the drawings.

S.V. Kashaev, relying on ceramic finds, dated this burial to the second half or the end of the 3rd century. ${ }^{14}$ Such a dating, in general terms, is quite possible, but other items found in this tomb do not easily correspond with this conclusion.

12 Максимова 1979: 118-121, 120, рис. 54.

13 Ор. cit.: 114-115, 118, рис. 52.

14 Кашаев 2013: 396.
The gold impression is likely to have been based on the reverse of a Rhodian coin (Fig. 4, 1; $5,1)$. We can see in this image a copy of the typical figure of a flower, a 'rose' (or a pomegranate flower), well-known from Rhodian coins and Rhodian stamped amphora handles. Coins bearing images of this type were minted in Rhodes in the 3rd and 2nd centuries BC (Fig. 5, 2-3). It should be noted that finds of imported coins in the Bosporus are very rare. As far as Rhodian coins are concerned, there are only 10 known, all of which come from the Taman peninsula. ${ }^{15}$.

Gold impressions (coin-shaped appliques) were widespread in the funeral practice of the Greek states of the Northern Black Sea region. ${ }^{16}$ But, I know only one disc copying a Rhodian coin from all this region: the impression from the Tuzla tumulus. Of course, the important role of Rhodes in trade with the Bosporan Kingdom in the Hellenistic time makes the appearance of such an object as very significant.

The golden wreath is an important element of the aristocratic graves of Bosporus. ${ }^{17}$ Judging by the figure (Fig. 4, 4), it is made quite carefully. The sheets incorporate the base tube of the wreath; for this reason, the wreath imitates a laurel branch quite realistically, which is typically traditional for Classical and early Hellenistic time. In the later Hellenistic period, however, the sheets were simply tied onto the base, good examples of this tradition can be seen on wreathes from the Artyukhovsky kurgan. ${ }^{18}$

15 Розов 2014: 281.

16 Калашик 2013; Журавлев и др. 2017: 169-190,

329-349, табл. 96-116.

17 Трейстер 2014.

18 Максимова 1979: 41-44, рис. 4-5. 


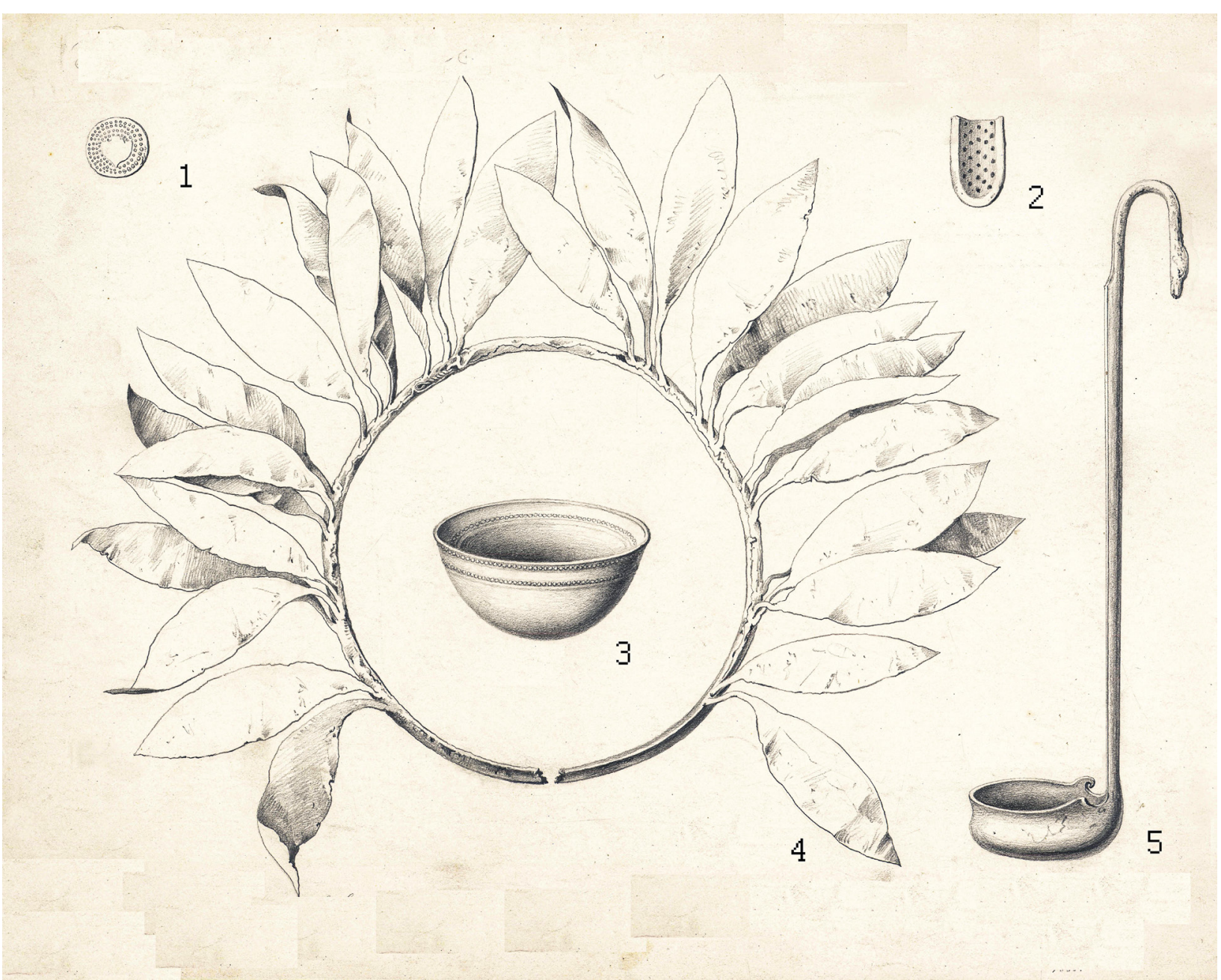

Fig. 4. Finds from Tomb 57 (drawing by F.I. Gross)

The silver ladle (Fig. 4, 5), by which the wine was poured out into cups (Fig. 4, 5), corresponds well to the type characteristic for the late Hellenistic period, with its deeper scoop when compared to earlier objects. ${ }^{19}$ Similar ladles were found in the Artyukhovsky kurgan. ${ }^{20}$ A silver strainer (Fig. 4, 2) is clearly connected with the wine sphere, but it seems to have no analogies among the repertoire of Bosporus archaeology.

A silver round bottom bowl (Fig. 4, 3 ) is very typical for late Hellenistic times. D. Strong attributed this type to the period after $200 \mathrm{BC}$. He singled out two main forms: a deep hemispherical bowl, and a deep conical bowl, proposing for both the name mastos ${ }^{21}$ which, in principle, is permissible. These vessels are usually not decorated on the outside, but on the inside they are often decorated with a frieze of a relief pearls under the rim, and sometimes have

19 Strong 1966: 92, fig. 21.

20 Максимова 1979: 87-88, рис. 30.

21 Strong 1966: 107-109, fig. 24. a rich floral decoration on the bottom. Such richly ornamented bowls, marking the first step towards the Hellenistic koine, date back to the 3rd century $\mathrm{BC}$, most probably to the second half rather than earlier. ${ }^{22}$ The Tuzla bowl belongs to this koine, i.e. to the 2 nd century $\mathrm{BC}$, although not fully. It is decorated with pearls, not only on the outside, but on the inside too. In the Bosporus region, such vessels are known from rich burials, which cannot be dated before the 2nd century BC: Buerova Mogila, the Akhtanizovsky hoard, and, of course, Artyukhovsky kurgan. ${ }^{23}$

In addition to the items which have been mentioned already, an iron knife and a piece of 'red powder' are listed in the excavation report. What kind of powder it was is not clear. Of course, it may

22 Bothmer von 1984: 54; Мордвинцева, Трейстер 2007: 28.

23 Спицын 1909: 22, № 17; Максимова 1979: 8082, рис. 26; Мордвинцева, Трейстер 2007: 29-30, Kat. 7, 2-3, А26.1, В1.1; Власова 2009: 67-68, т абл. 1, 2. 

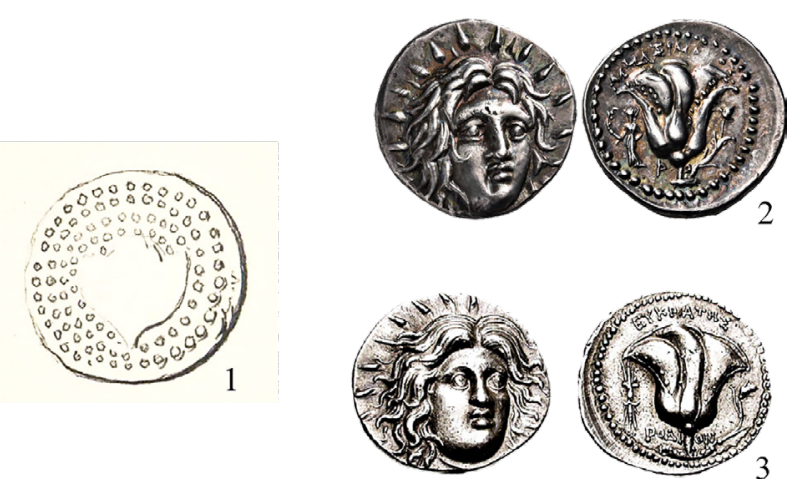

Fig. 5. Gold impression from Tomb 57 (1) and silver Rhodian coins (2-3)

have been rouge, then it would be logical to suppose that the burial belonged to the woman. However, the inventory of the burial would not correspond with such an attribution. It is most probable that tomb no. 57 belonged to a male. Items normally associated with female burials, such as a mirror, beads, ear-rings, etc. are absent.

One obvious fact about the grave furnishings of the tomb is that they are all recognizably Greek. There are no finds that could be confidently associated with the world of the barbarian tribes. In this context, however, that 'piece of leather' (obviously a leather bag) with red powder looks somewhat out of place. Nothing of this kind ever features in rich male burials of the Bosporus. However, if is not rouge, then what can it be?

The answer to this question, perhaps, should be found outside the Greek world. In burials of Savromats and early Sarmatians (the Prokhorov archaeological culture), pieces of coal, chalk, ochre etc. are found frequently. ${ }^{24}$ It is believed that, in the religious system of faith of these ancient peoples, an important place was occupied by such interrelated concepts as 'sun - light - fire'. ${ }^{25}$ This belief system the Sarmatians brought with them during their migration to the Kuban river region. ${ }^{26}$ Sarmatian influences can be detected among the materials coming from some of the elite funeral monuments of the Bosporus of the Hellenistic era (Ak-Burun, Zelenskoi Kurgan, Buerova Mogila, etc.). ${ }^{27}$ But this is another and very important subject and worthy of separate study elsewhere.

Tomb No. 57 of the Fifth barrow of the Tuzla necropolis expands our understanding of the culture

\footnotetext{
24 Мошкова 1963: 23; Смирнов 1964: 94-96.

25 Смирнов 1989: 165.

6 Марченко 1996: 98, 111-112.

27 Виноградов 2017б: 176-182, 210-215.
}

of the aristocracy of the Asian Bosporus during the Hellenistic period. Until the complete publication of this complex, there can be no certainty that its dating is limited to the second half or towards the end of the 3rd century BC. It is quite possible that it projects into the 2 nd century, but it is almost certain that the Tuzla grave complex dates $t$ a period preceding the construction of the Artyukhovsky kurgan. According to M.I. Maximova, the burials of this latter mound was made in the middle to the third quarter of the 2 nd century BC. ${ }^{28}$

Almost all the elite burials of the Asian Bosporus, belonging to the 3rd and 2nd centuries $\mathrm{BC}$ have been robbed. We cannot speak about the elite burial structures of the European Bosporus at this time at all: the evidence simply does not exist. ${ }^{29}$ Without going deeply into discussion on this subject, it possible to recognize that the chamber opened by F.I. Gross in the Tuzla necropolis deserves the serious scientific attention. After all, this chamber, along with some others, makes it possible to judge that influence of Rhodes on the culture of the Bosporan aristocracy from the end of the 4th down to the early 2 nd centuries $\mathrm{BC}$ was strongly felt.

It is quite very astonishing that this monument has not been subject to the attention of the scientific world for 130 years! We have finally put an end to this strange and illogical situation.

\section{Literature}

Bothmer, D. von. 1984. A Greek and Roman Treasury. The Metropolitan Museum of Art Bulletin, 42 , no. 1.

Gorbunova, X., I. Saverkina. 1975. Greek and Roman Antiquities in the Hermitage. Leningrad: Aurora Art Publishers.

Mordvinceva, V. 2001. Sarmatische Phaleren. Archäologie in Eurasien, 11.

Strong, D. E. 1966. Greek and Roman Gold and Silver Plate. London: Methuen \& Co.

Trofimova, A.A. (ed.). Greeks on the Black Sea. Ancient Art from the Hermitage. Los Angeles: J. Paul Getty Museum.

Виноградов, Ю.А. 2006. Ещё раз о дате Феду ловского к л ада B: In situ: К 85-летию профе ссора А.Д. Столяра / отв. ред. А.А. Никонова. С-Петербург: Издательство Санкт-Петербургского университет а, 207-227.

\footnotetext{
28 Максимова 1979: 8-9, 23.

29 Виноградов 2017б: 194-195, 204, 215-216.
} 
Виноградов, Ю.А. 2016. Богатое эллинистическое погребение Тузлинского некрополя В: Азиат ский Бо спор и Прикубанье в доримско е время. Материалы Международного круглого стола 7-8 июня 2016 г. / науч. ред. Д.В. Журавлёв, У. Шлотцауер. Мо сква: Государственный историче ский музей, 1922.

Виноградов, Ю.А. 2017а. Древности Боспора Киммерийского в рисунках К. Р. Бегичева и Ф. И. Гросса (по материал ам Научного архива ИИМК РАН). Бо спорские исследования. Supplementum 17. Симферополь-Керчь: Издательство ОООО «Соло-Рич».

Виноградов, Ю.А. 2017б. Культура боспорской элиты при Спартокидах В: Элит а Бо спора Киммерийского: т радиции и инновации в аристократиче ской культуре доримского времени. Бо спорские исследования 34, 112 223.

Виноградов, Ю.А., В.Н. Зинько, Т.Н. Смекалова. 2012. Юз-Оба. Курганный некрополь аристократии Боспора. Т. I. История изучения и топография. Симферополь Керчь: Май- стер Книг, 2012.

Власова, Е.В. 2009. Ахтанизовский клад // Вестник древней истории 3, 63-78.

Журавлев, Д.В., Е.Ю. Новикова, С.А. Кова ленко, М.С. Шемаханская. 2017. Зол ото Херсонеса Таврического (Ювелирные изд елия из собра- ния Государственного исторического музея). Москва: РИА Внешторгиздат.

Засецкая, И.П. 1965. Назначение вещ ей Федуловского кл ада В: Археологиче ский с борник Го сударственногоЭрмт ажа 7, 28-36.

Калашник, Ю.П. 2013. Пантикапейские индикаuиии // Фидития. Памяти Юрия Викторовича Андреева / ред. Ю.А. Виноградов и др. С-Петербург: Дмит рий Буланин, 8599.

Кашаев, С.В. 2013. Тузлинские курганы (по ма- териал ам публикаций и архивов) В: Российский археологиче ский ежегодник 3 , 360-409.
Кац, В.И. 2007. Грече ские керамиче ские клейма эпохи классики и эллинизма (опыт комплексного изучения). Бо спорские исследования, 18.

Максимова, М.И. 1979. Артюховский курган. Ленинград: Искусство.

Марченко, И.И. Сираки Кубани (по материал ам курганных погребений Нижней Кубани). Краснодар: Краснодарский Го сударственный университет.

Мордвинцева, В.И., М.Ю. Трейстер. 2007. Произвед ения торевтики и ювелирного искусства в Северном Причерноморье II в. до н.э.II в. н.э. Т. 1-3. Симферополь - Бонн: Тарпан. Мошкова, М.И. 1963. Памятники прохоровской культуры. Свод археол огических источников СССР. Вып. Д1-10. М.: Наука.

Розов, В.Н. Новые находки греческих привозных монет на территории Таманского полуострова В: Древно сти Бо спора 18, 272-307.

Смирнов, К.Ф. 1964. С авроматы. Ранняя история и культура сарматов. М.: Наука.

Смирнов, К.Ф. 1989. Савроматская и раннесарматские культуры В: Археология СССР. Степи европейской части СССР в скифо-с армат ско е время. / А. И. Мелюкова (отв. ред.). М.: Наука, 165-177.

Сорокина, Н.П. 1957. Тузлинский некрополь. Труды Го сударственного историче ского му- зея «Памятники культуры» 26. Мо сква: Со- вет ская Ро ссия.

Спицын, А.А. 1909. Фал ары южной России В: Изве стия Императ рской Археологиче ской Комиссии 29, 18-53.

Трейстер, М.Ю. 2014. Зол отые погребальные венки Боспора $I V$ в. до н.э.-V в. н.э. (генезис и хронол огия основных типов) В: Погреба льная культура Бо спорского царства. Ма териа лы Круглогого стола, по свящённого 100-летию со дня рождения М.М. Кубланова / отв. ред. Ю.В. Зуев и В.А. Хршановский. С-Петербург: Не стор-История, 54-65.

Шелов, Д.Б. 1975. Керамические к л ейма из Taнаиса III-I вв. до н.э. Мо сква: Наука.

Yurii A. Vinogradov ORCID 0000-0002-4447-5679

Institute for History of Material Culture RAS

St. Petersburg, Russia vincat2008@yandex.ru 